Electronic Supplementary Material (ESI) for Energy \& Environmental Science.

This journal is (C) The Royal Society of Chemistry 2021

\title{
Catalytic Open-circuit Passivation by Thin Metal Oxide Films of p-Si Anodes in Aqueous Alkaline Electrolytes
}

Harold J. Fu' $u^{\mathrm{a}}$ Pakpoom Buabthong ${ }^{\mathrm{b}}$, Zachary P. Ifkovits ${ }^{\mathrm{a}}$, Weilai Yu ${ }^{\mathrm{a}}$, Bruce S. Brunschwig ${ }^{\mathrm{c}}$, Nathan S. Lewis ${ }^{\mathrm{a}, \mathrm{c}}$

a'Division of Chemistry and Chemical Engineering, 127-72, California Institute of Technology, Pasadena, CA 91125, USA

${ }^{\mathrm{b}}$ Division of Engineering and Applied Sciences, California Institute of Technology, Pasadena, CA 91125

'Beckman Institute Molecular Materials Resource Center, California Institute of Technology, Pasadena, CA 91125, USA

*Correspondence to: nslewis@ caltech.edu,bsb@caltech.edu 


\section{Supplementary Information}

\section{Supplemental Experimental Methods}

The procedure for determining $\mathrm{Si}$ etch rate in $\mathrm{KOH}$ (Fig. S1) can be found in a previous work. ${ }^{1}$ Briefly, a Si wafer was subjected to $950{ }^{\circ} \mathrm{C}$ for $6 \mathrm{~h}$ in air to grow a thermal oxide. A 10 $\mu \mathrm{m}$ by $100 \mu \mathrm{m}$ array of rectangles was patterned using the same photolithography procedures as above. The patterned wafers were etched in BOE for 3 min to create trenches and the photoresist was removed with acetone. The samples were cleaved and made into electrodes. The electrodes were tested in a standard 3-electrode cell with $1 \mathrm{M} \mathrm{KOH(aq)} \mathrm{and} \mathrm{a} \mathrm{potential} \mathrm{was} \mathrm{applied.} \mathrm{After}$ $20 \mathrm{~h}$, the sample was removed from the electrode and submerged in BOE for $5 \mathrm{~min}$ to remove the thermal oxide. AFM was used to quantify height differences between the not etched $\mathrm{Si}$ surface (previously underneath the thermal oxide) and the exposed trenches.

The $\mathrm{p}^{+}-\mathrm{Si} / \mathrm{Ni}$ islands $(\mu \mathrm{Ni})$ electrode depicted in Fig. S7 was fabricated using photolithography and Ni sputtering as described in a previous work. ${ }^{1}$ Briefly, the Si wafer was RCA2 cleaned and dried before applying primer and Shipley 1813 positive photoresist via spin coater. The wafer was cured on a hot plate at $110{ }^{\circ} \mathrm{C}$ for $1 \mathrm{~min}$ and then exposed to UV light under a mask aligner. The chrome mask used produced an array of $3 \mu \mathrm{m}$ diameter holes in the photoresist with $7 \mu \mathrm{m}$ pitch. The pattern was developed in MF-319 for 2 min and baked at 110 ${ }^{\circ} \mathrm{C}$ for $1 \mathrm{~min} .60 \mathrm{~nm}$ of $\mathrm{Ni}$ was sputter deposited. The photoresist was removed by sonicating the sample in acetone.

Amorphous $\mathrm{TiO}_{2}$ films used in Fig. S9, S10, and S12 were deposited on cleaned Si via ALD (Cambridge Nanotech S200). For each ALD cycle, a 0.10 s exposure to TDMAT was followed by a $15 \mathrm{~s}, 20 \mathrm{sccm} \mathrm{N}_{2}$ purge, a $0.015 \mathrm{~s}$ exposure to $\mathrm{H}_{2} \mathrm{O}$, and another $\mathrm{N}_{2}$ purge. The 
deposition chamber was held at $150{ }^{\circ} \mathrm{C}$ and the TDMAT precursor was held at $75{ }^{\circ} \mathrm{C}$ throughout the deposition. A 1500 cycle was prepared leading to a $70 \mathrm{~nm}$ film as measured by spectroscopic ellipsometry (J.A. Woollam Co., alpha-SE).

\section{Supplementary Information Figures}
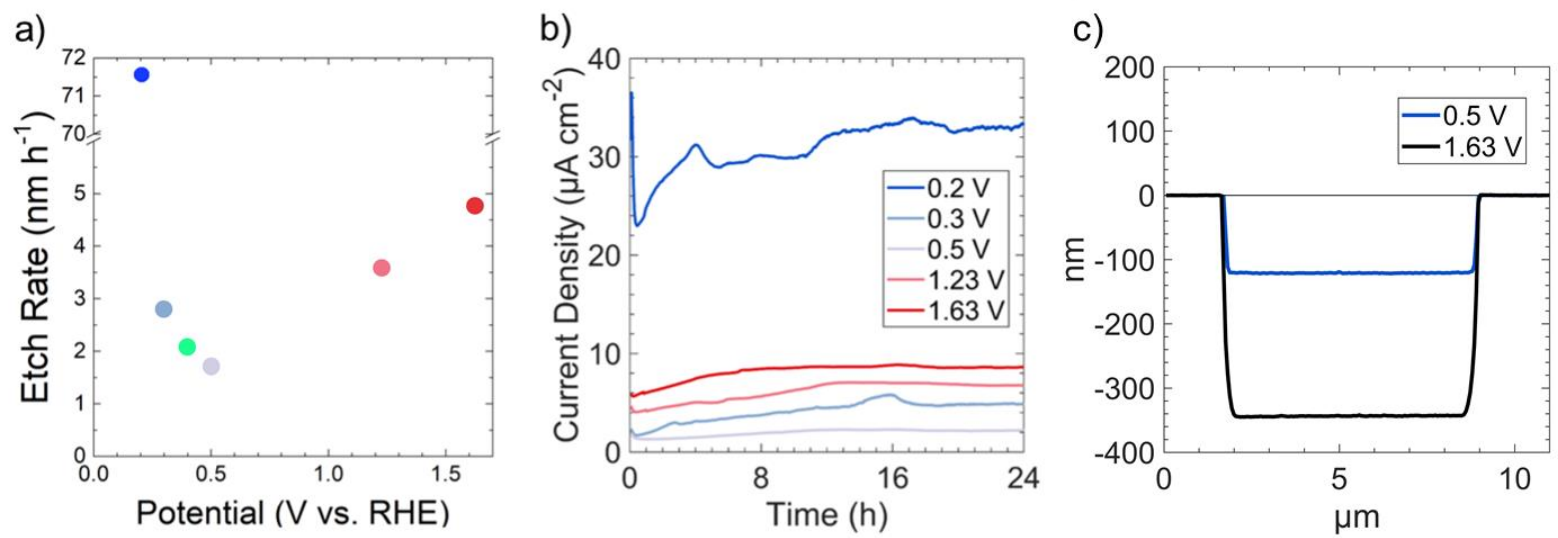

Figure S1. (a) Dissolution rate of $\mathrm{p}^{+}-\mathrm{Si}(100)$ in $1 \mathrm{M} \mathrm{KOH}(\mathrm{aq})$ in the dark at various potentials and (b) the corresponding chronoamperogram over a $24 \mathrm{~h}$ period. (c) Cross-section of $\mathrm{p}^{+}-\mathrm{Si}(100)$ representative etch pits under $0.5 \mathrm{~V}$ (blue) and $1.63 \mathrm{~V}$ (black) vs RHE in $1 \mathrm{M} \mathrm{KOH}(\mathrm{aq})$ for $72 \mathrm{~h}$.

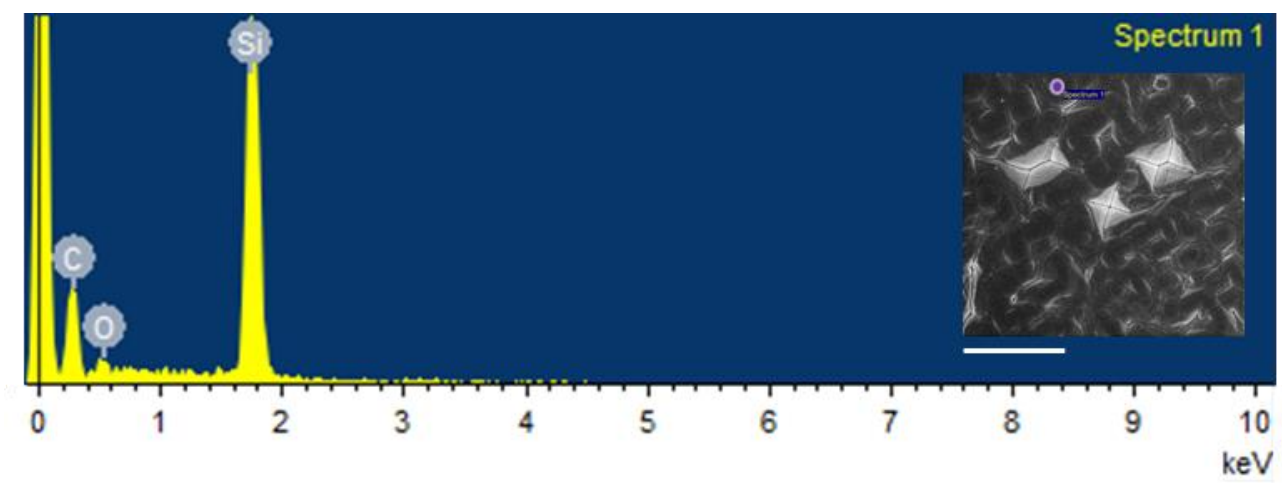

Figure S2. Energy dispersive X-ray spectrum of $\mathrm{p}^{+}-\mathrm{Si} / \mathrm{Ni}(5 \mathrm{~nm})$ after $120 \mathrm{~h}$ in $\mathrm{N}_{2}$-saturated $1 \mathrm{M}$ $\mathrm{KOH}(\mathrm{aq})$. Inset shows corresponding scanning electron micrograph; the purple dot indicates location of scan. Scale bar is $10 \mu \mathrm{m}$. 
a) $120 \mathrm{~h}$

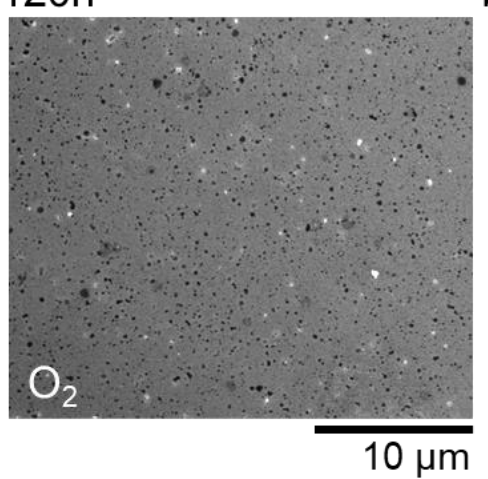

b) $20 \mathrm{~h}$

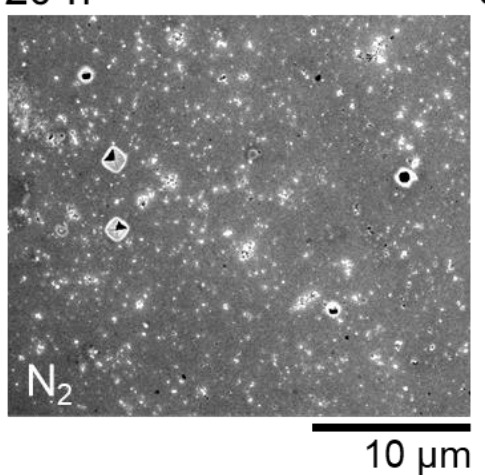

c) $120 \mathrm{~h}$

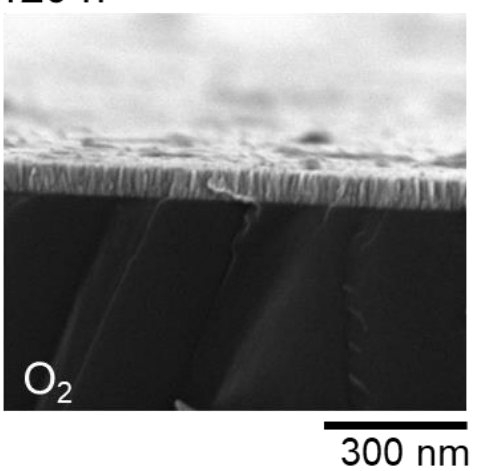

Figure S3. (a-b) Top-down scanning electron micrographs of $\mathrm{p}^{+}-\mathrm{Si}(100) / \mathrm{NiO}_{\mathrm{x}}$ electrodes in $1 \mathrm{M}$ $\mathrm{KOH}\left(\mathrm{aq}\right.$ ) at open circuit saturated with (a) $\mathrm{O}_{2}$ for $120 \mathrm{~h}$ and (b) $\mathrm{N}_{2}$ for $20 \mathrm{~h}$. (c) Cross section of sample in (a) showing the $\mathrm{NiO}_{\mathrm{x}}$ coating on the $\mathrm{Si}$ substrate.

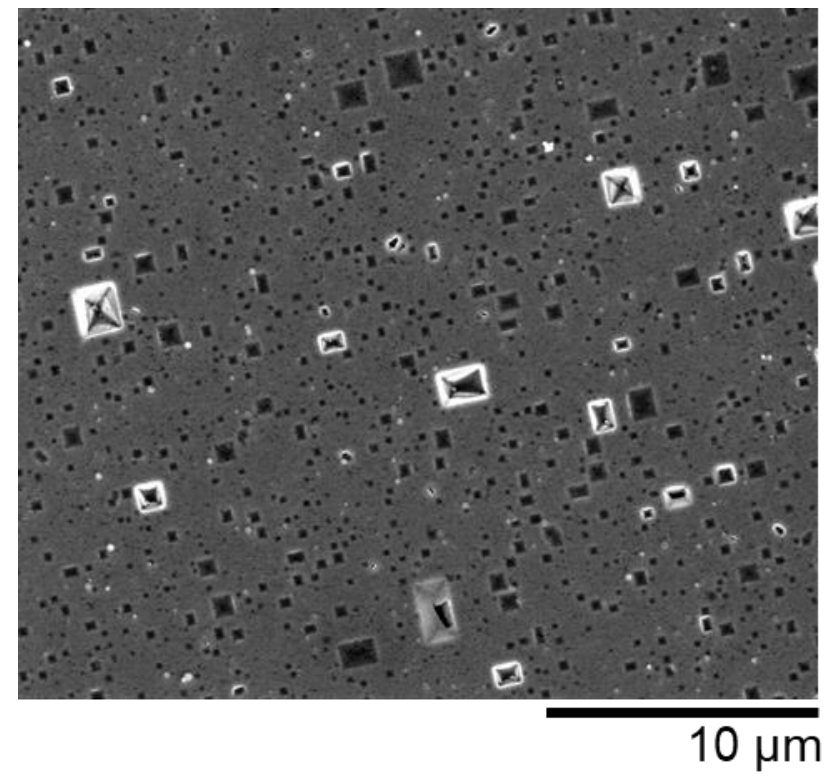

Figure S4. Scanning electron micrograph of $\mathrm{p}^{+}-\mathrm{Si}(100) / \mathrm{Ni}(5 \mathrm{~nm})$ after being potentiostatically held at $-0.1 \mathrm{~V}$ vs RHE for $20 \mathrm{~h}$ in $\mathrm{O}_{2}$-saturated $1 \mathrm{M} \mathrm{KOH}(\mathrm{aq})$. 

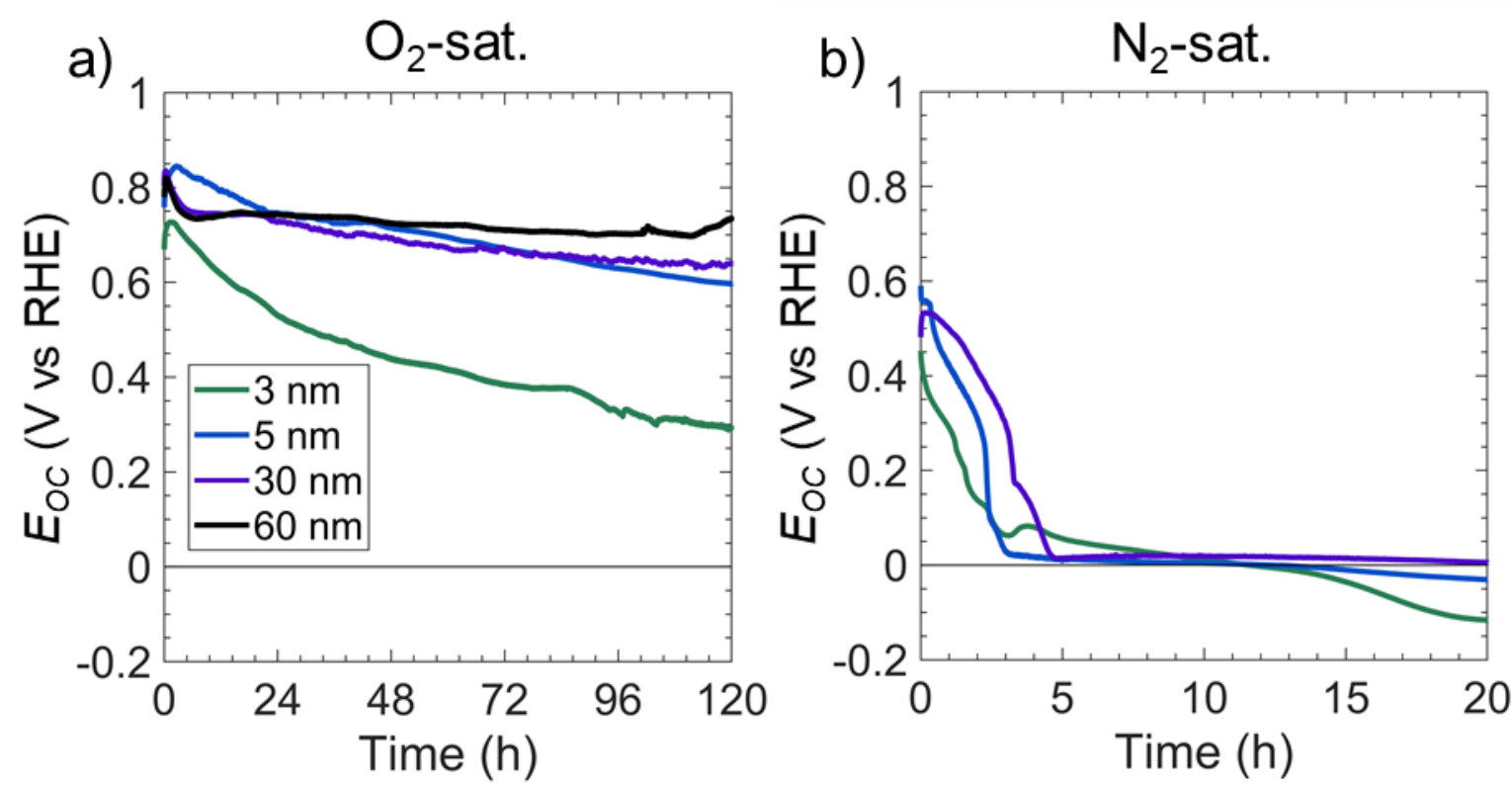

Figure S5. Comparison of open-circuit potential vs time for $\mathrm{p}^{+}-\mathrm{Si} / \mathrm{Ni}$ electrode with $\mathrm{Ni}$ film thicknesses at $3 \mathrm{~nm}$ (green), $5 \mathrm{~nm}$ (blue), $30 \mathrm{~nm}$ (purple), and $60 \mathrm{~nm}$ (black, (a) only) in (a) $\mathrm{O}_{2-}$ and (b) $\mathrm{N}_{2}$-saturated $1 \mathrm{M} \mathrm{KOH}(\mathrm{aq}$ ) solution. 
a)

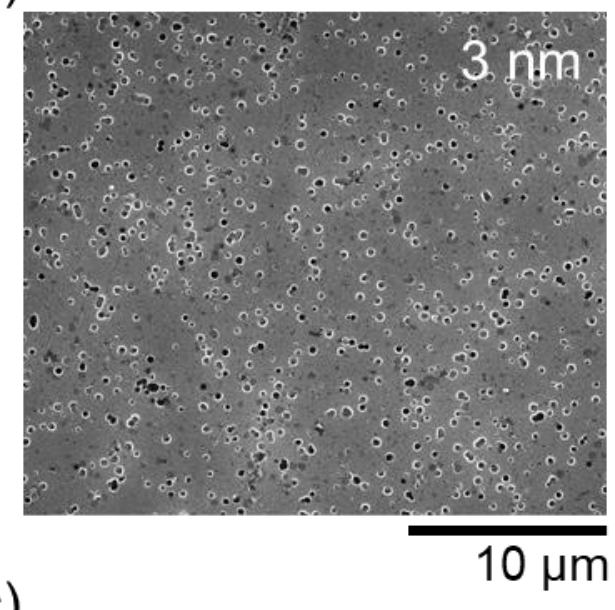

c)

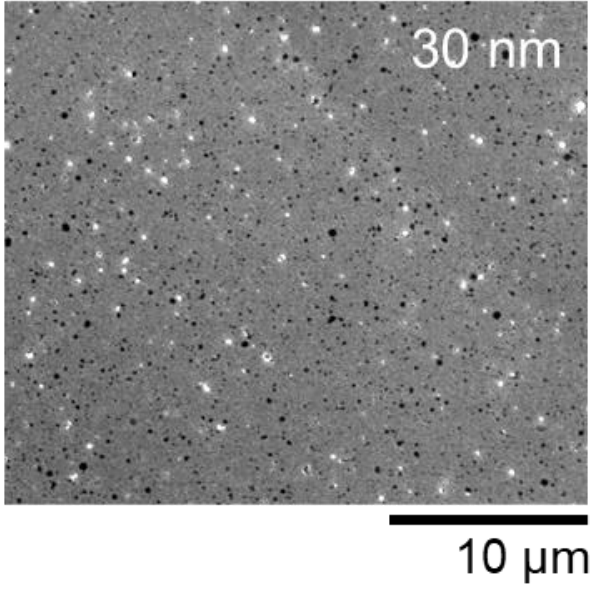

b)

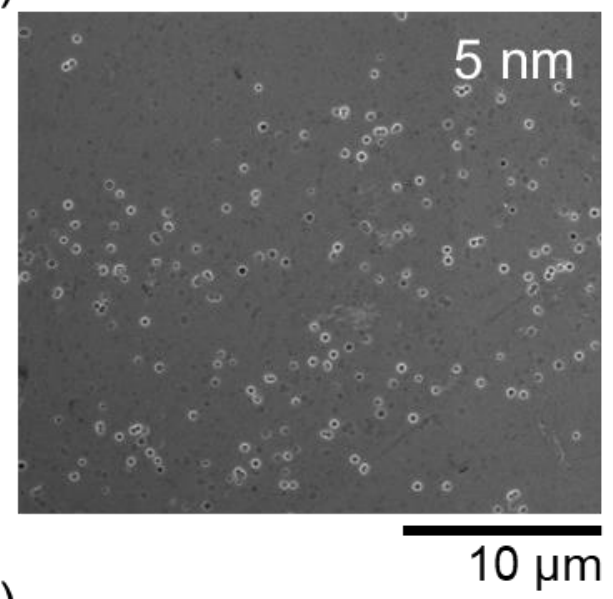

d)

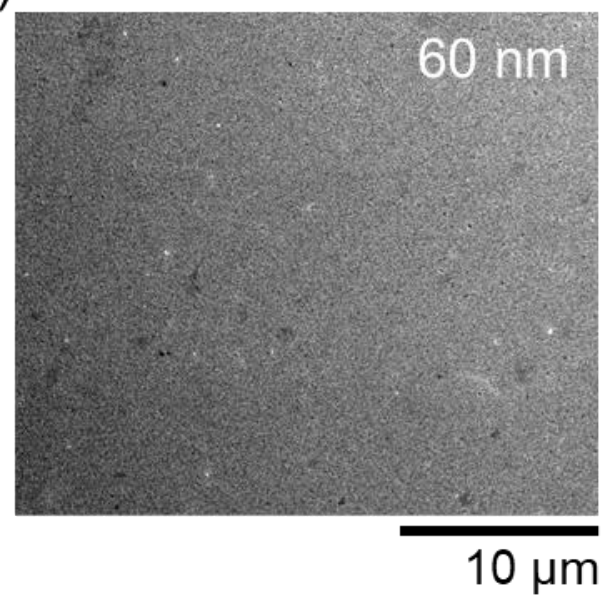

Figure S6. Scanning electron micrographs of $\mathrm{p}^{+}-\mathrm{Si}$ deposited with $\mathrm{Ni}$ film thicknesses at (a) 3 $\mathrm{nm}$, (b) $5 \mathrm{~nm}$, (c) $30 \mathrm{~nm}$, and (d) $60 \mathrm{~nm}$ after $120 \mathrm{~h}$ at open circuit in $\mathrm{O}_{2}$-saturated $1 \mathrm{M} \mathrm{KOH}(\mathrm{aq})$. 


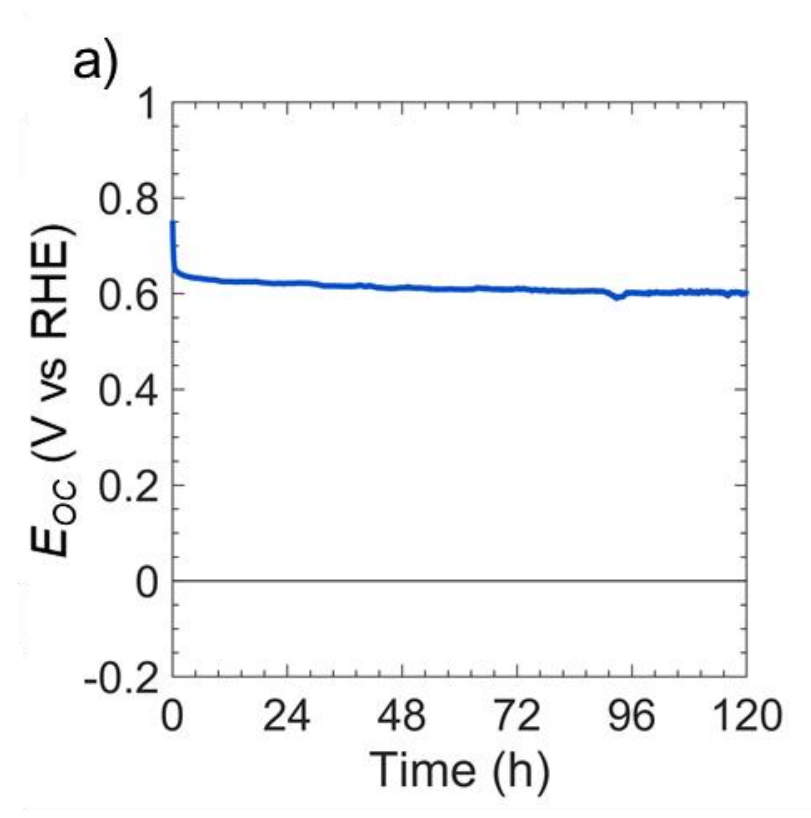

b)

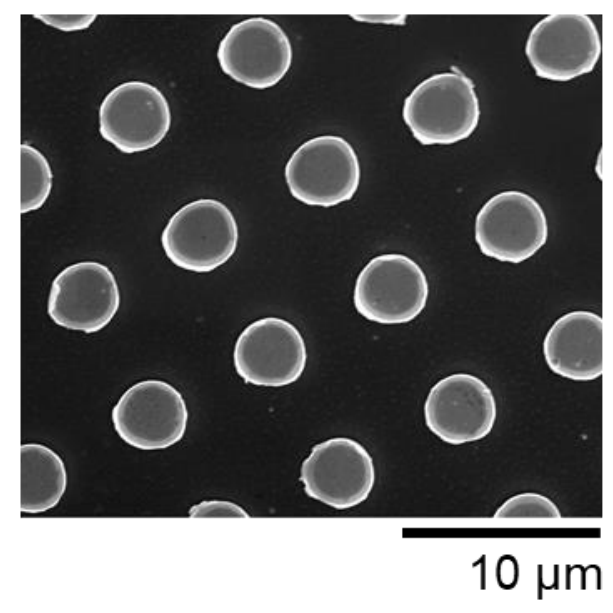

Figure S7. Catalyzed passivation of exposed Si using Ni islands ( $\mu \mathrm{Ni}$ ) in $1 \mathrm{M} \mathrm{KOH}$. (a) Opencircuit potential vs time of $\mathrm{p}^{+}$-Si decorated with $60 \mathrm{~nm}$ thick $\mu \mathrm{Ni}$ in $\mathrm{O}_{2}$-saturated, $1 \mathrm{M} \mathrm{KOH}(\mathrm{aq})$. (b) Scanning electron micrograph of $\mathrm{p}^{+}-\mathrm{Si} / \mu \mathrm{Ni}$ after testing for $120 \mathrm{~h}$. An array of $3 \mu \mathrm{m}$ diameter $\mu \mathrm{Ni}$ covered $\sim 14 \%$ of the Si surface.

a)

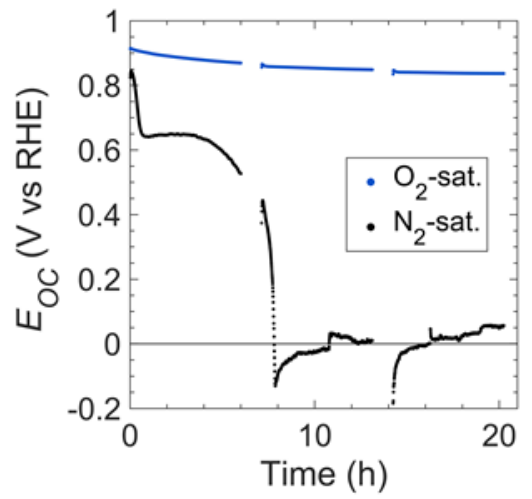

b)

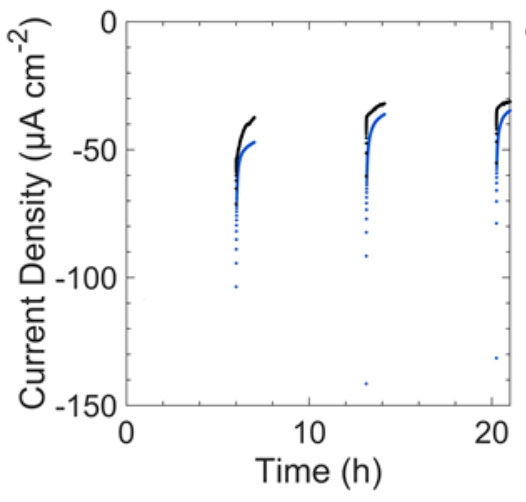

c)

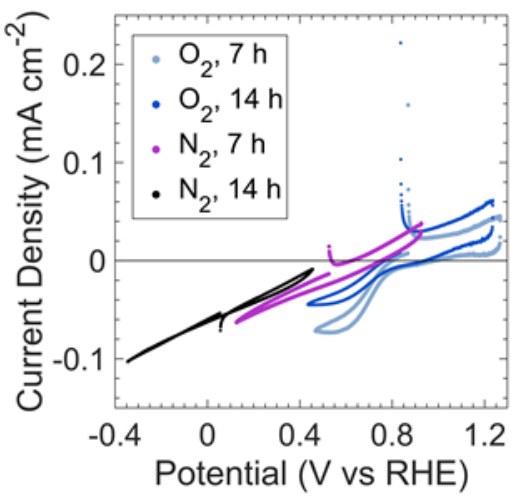

Figure S8. Electrochemical data of $\mathrm{p}^{+}-\mathrm{Si} / \mathrm{NiO}_{\mathrm{x}}(60 \mathrm{~nm})$ electrodes in $1 \mathrm{M} \mathrm{KOH}(\mathrm{aq})$ in the dark. (a) Open-circuit potential $\left(E_{\mathrm{oc}}\right)$ vs time over $6 \mathrm{~h}$ intervals in $\mathrm{O}_{2}$-saturated (blue) or $\mathrm{N}_{2}$-saturated (black) solutions. (b) Chronoamperogram at $0.3 \mathrm{~V}$ vs RHE for $1 \mathrm{~h}$ taken at 6,13 , and $20 \mathrm{~h}$ after the $E_{\text {oc }}$ measurements in (a). (c) Cyclic voltammograms in $\mathrm{O}_{2-}$ (light blue and blue) or $\mathrm{N}_{2}-$ saturated (purple and black) solutions taken after 7 and $14 \mathrm{~h}$ cycles, respectively. The scans were cycled from $E_{\text {oc }}$ to $+0.4 \mathrm{~V}$ to $-0.4 \mathrm{~V}$ vs $E_{\text {oc }}$ at $10 \mathrm{mV} \mathrm{s}^{-1}$. 


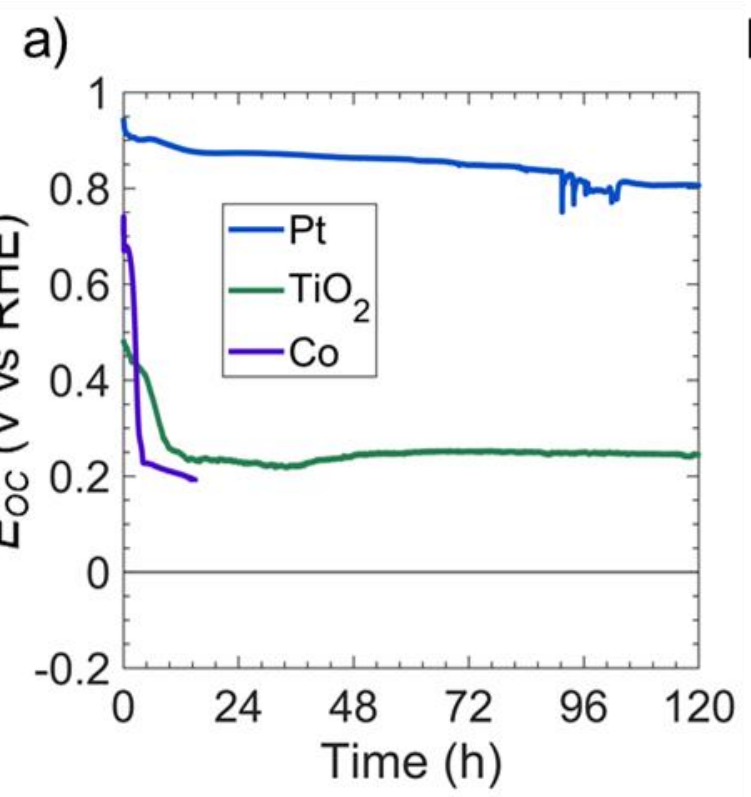

c)

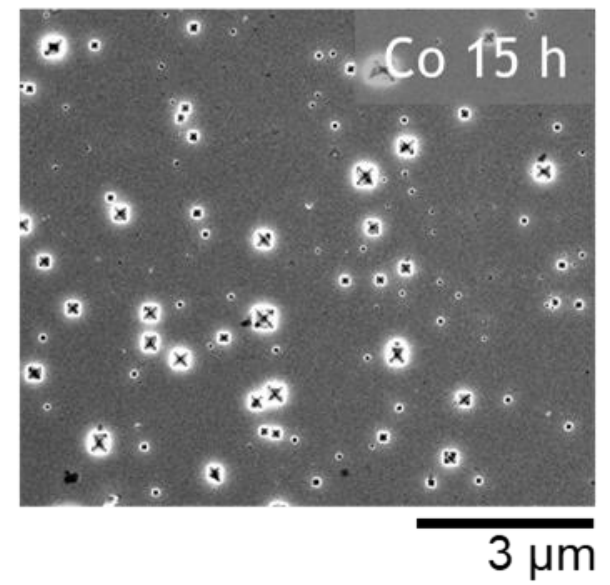

b)

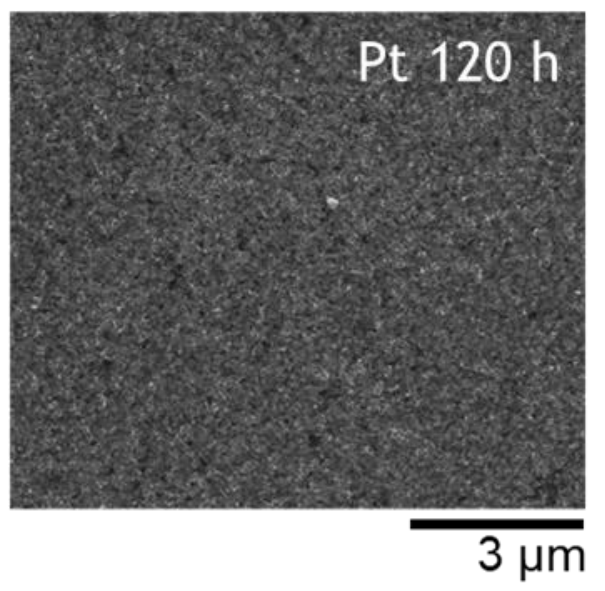

d)

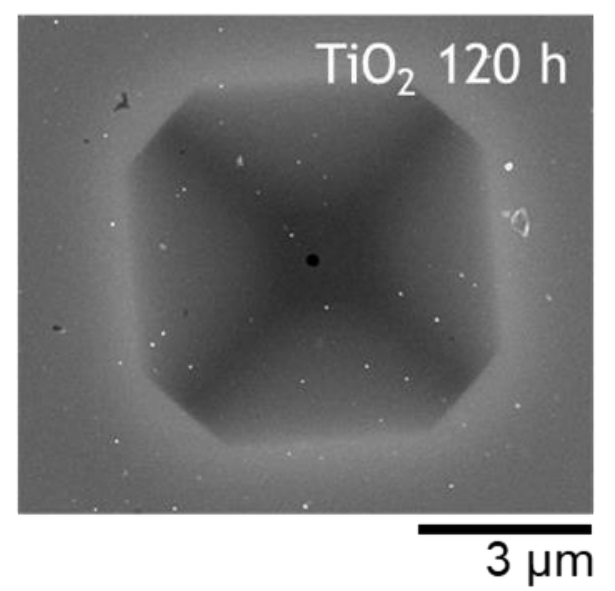

Figure S9. (a) Open-circuit potential vs time for $\mathrm{p}^{+}-\mathrm{Si}$ coated with $\mathrm{Pt}$ (blue), amorphous $\mathrm{TiO}_{2}$ (green), or Co (purple) thin films in $\mathrm{O}_{2}$-saturated $1 \mathrm{M} \mathrm{KOH}(\mathrm{aq})$. (b-d) Scanning electron micrographs of $\mathrm{p}^{+}-\mathrm{Si}$ coated with (b) $\mathrm{Pt}$, (c) $\mathrm{Co}$, or (d) $\mathrm{TiO}_{2}$ imaged after submerging in $\mathrm{KOH}$ for $120 \mathrm{~h}, 15 \mathrm{~h}$, and $120 \mathrm{~h}$, respectively. 


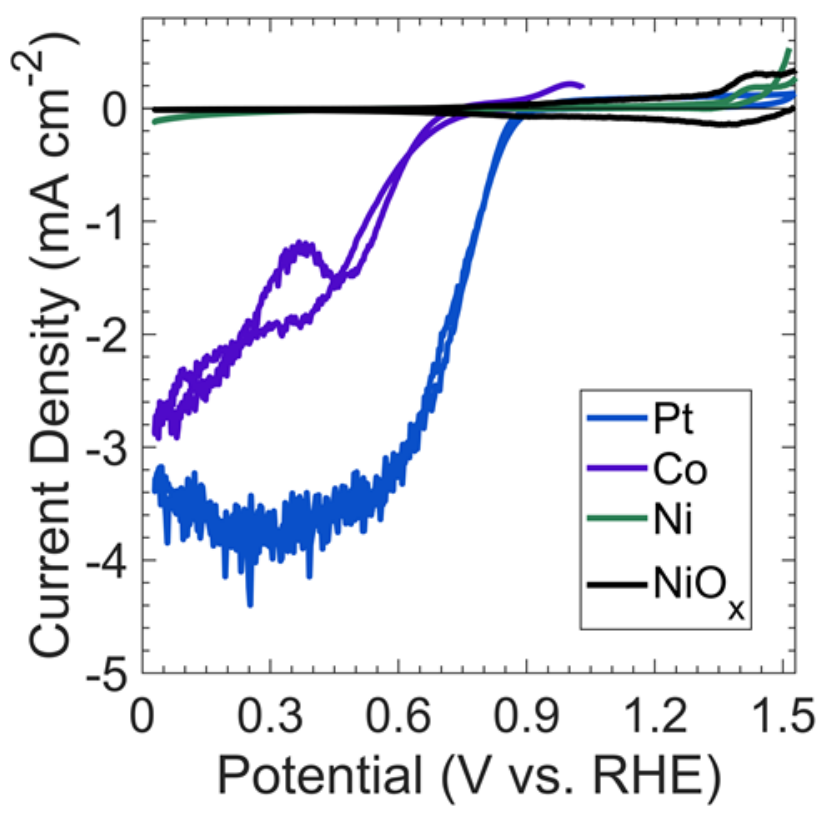

Figure S10. Cyclic voltammograms for the oxygen reduction reaction for Pt (blue), Co (purple), $\mathrm{Ni}$ (green), and $\mathrm{NiO}_{\mathrm{x}}$ (black) thin films on $\mathrm{n}^{+}-\mathrm{Si}$ in $1 \mathrm{M} \mathrm{KOH}(\mathrm{aq})$ under $\mathrm{O}_{2}$-saturation and vigorous stirring.

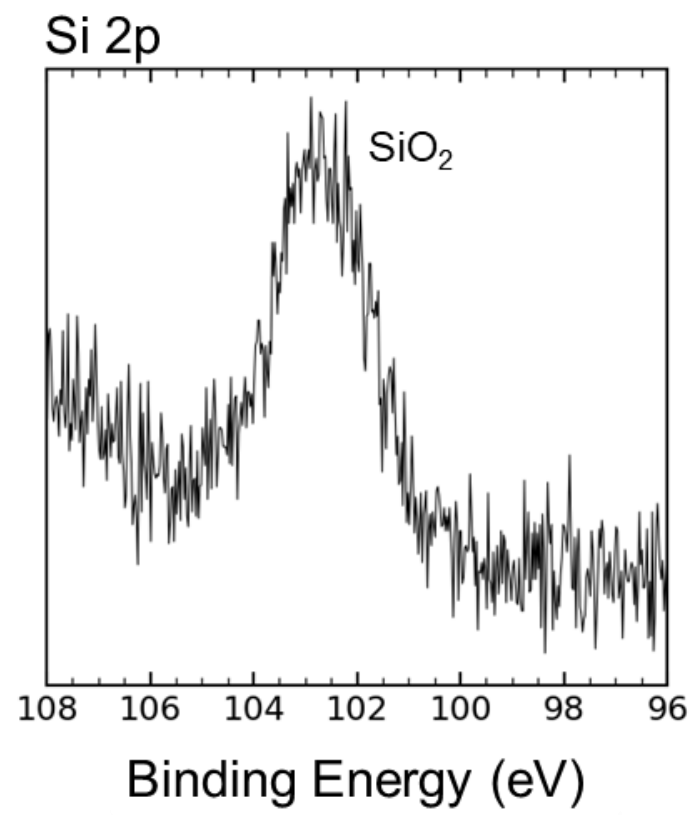

Figure S11. X-ray photoelectron spectrum in the $\mathrm{Si} 2 \mathrm{p}$ region of an $\mathrm{np}^{+}-\mathrm{Si} / \mathrm{NiO}_{\mathrm{x}}$ photoelectrode after extended stability testing under day/night cycling. The y-axis is in arbitrary units. 
a)

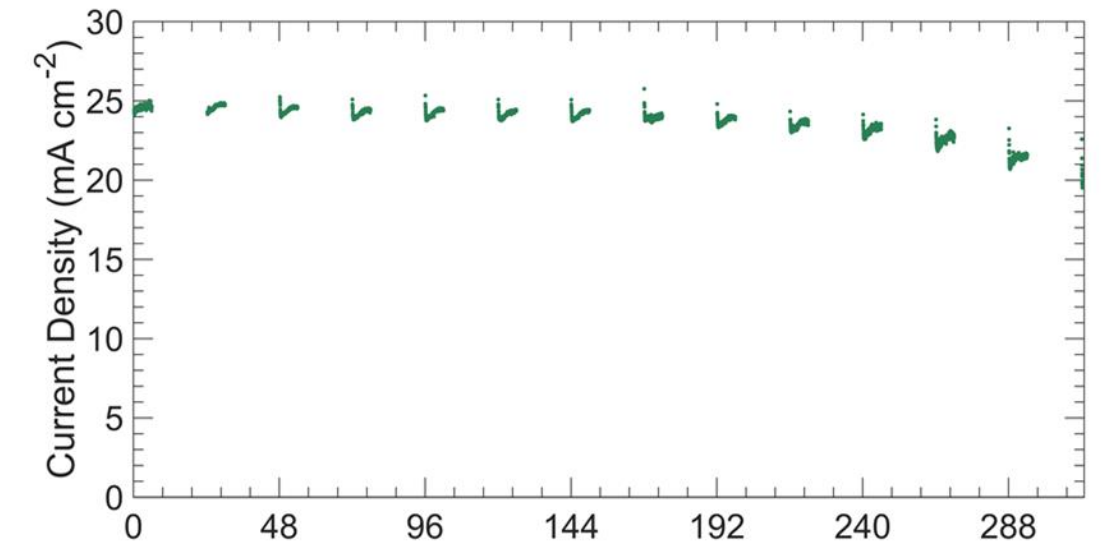

b)

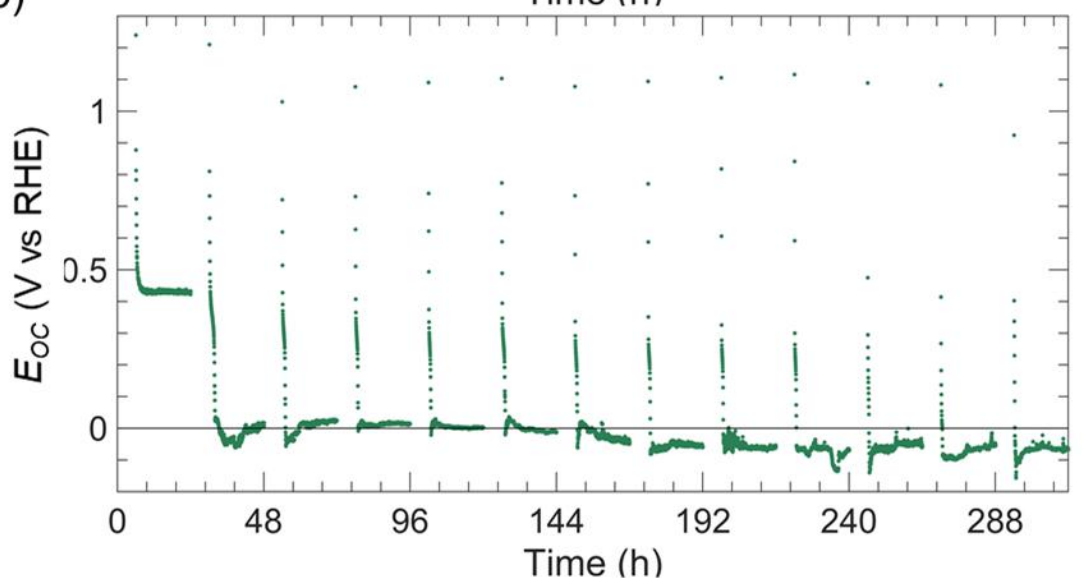

c)

d)
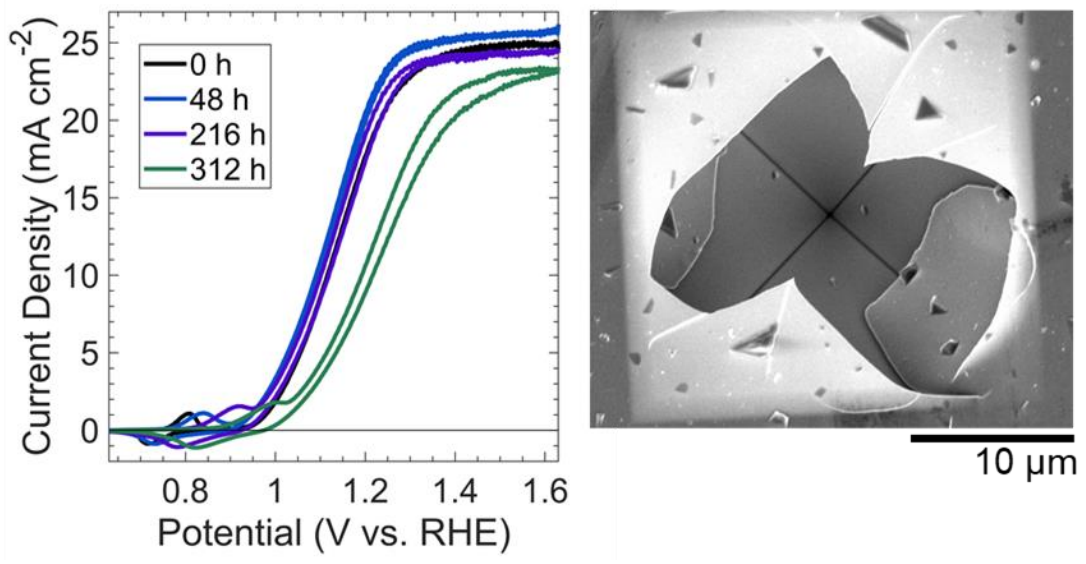

Figure S12. Stability and performance of $\mathrm{np}^{+}-\mathrm{Si} / \mathrm{TiO}_{2} / \mathrm{Ni}$ photoanode under day/night cycling in $\mathrm{O}_{2}$-saturated $1 \mathrm{M} \mathrm{KOH}(\mathrm{aq})$. (a) Chronoamperogram under $100 \mathrm{~mW} \mathrm{~cm}{ }^{-2}$ illumination and $1.63 \mathrm{~V}$ vs RHE for $6 \mathrm{~h}$ intervals. (b) Open-circuit potential vs time in the dark for $18 \mathrm{~h}$ intervals. (c) Cyclic voltammograms under 1 sun simulated illumination after $0 \mathrm{~h}$ (black), $48 \mathrm{~h}$ (blue), $216 \mathrm{~h}$ (purple), and $312 \mathrm{~h}$ (green) of testing (d) Scanning electron micrograph of photoanode after testing depicting a $\mathrm{Si}$ etch pit undercutting the $\mathrm{TiO}_{2} / \mathrm{Ni}$ layers. 
a)

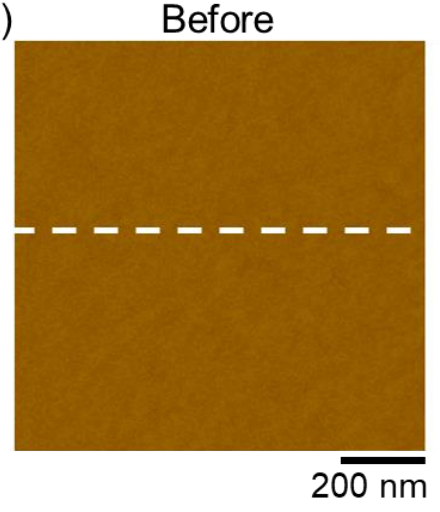

b)

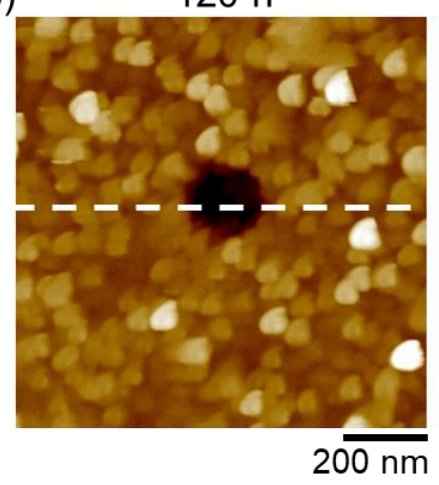

c)

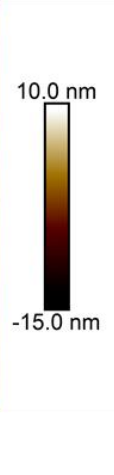

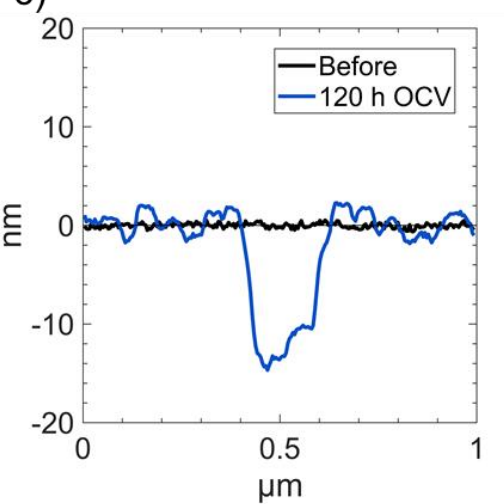

Figure S13. Atomic force microscope images of $\mathrm{p}^{+}-\mathrm{Si} / \mathrm{Ni}$ topography (a) before and (b) after 120 $\mathrm{h}$ submerging in $1 \mathrm{M} \mathrm{KOH}(\mathrm{aq})$ at open circuit. (c) Cross-section of electrode before (black) and after submerging in $\mathrm{KOH}$ (blue) at the indicated white dashed line in (a-b).

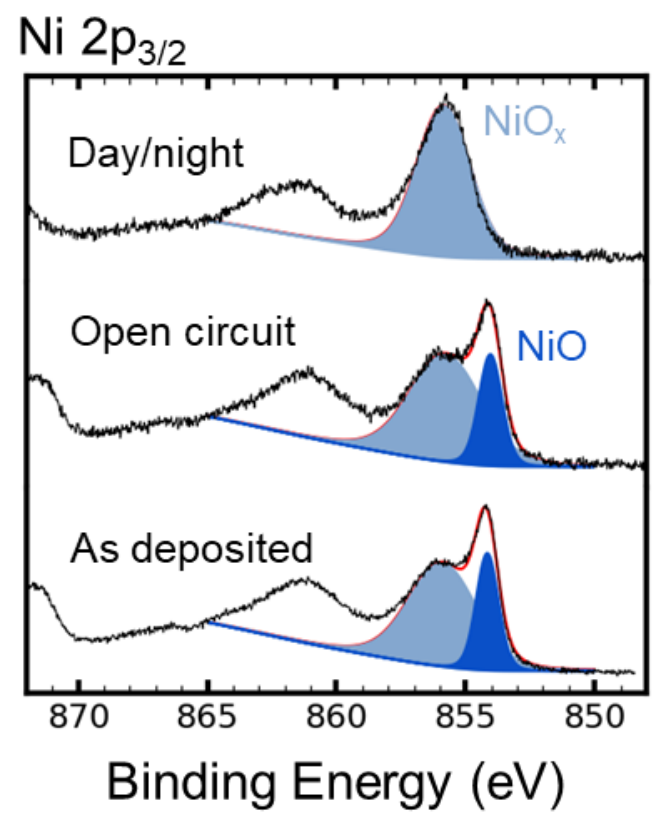

Figure S14. X-ray photoelectron spectroscopic data in the $\mathrm{Ni} 2 \mathrm{p}_{3 / 2}$ region of $n p^{+}-\mathrm{Si} / \mathrm{NiO}_{\mathrm{x}}$ electrodes. Electrodes were measured as deposited, after $20 \mathrm{~h}$ in $\mathrm{O}_{2}$-saturated $1 \mathrm{M} \mathrm{KOH}(\mathrm{aq})$ at open circuit, and after $410 \mathrm{~h}$ in $1 \mathrm{M} \mathrm{KOH}(\mathrm{aq})$ under simulated day/night cycling as described in Fig. 4. The Ni $2 p_{3 / 2}$ emission was fitted to two peaks. The dominant phase of the light blue peak is likely a mix of $\mathrm{NiO}$. $\mathrm{Ni}(\mathrm{OH})_{2}$, and $\mathrm{NiO}(\mathrm{OH})$ while that of the low energy peak (darker blue) is likely $\mathrm{NiO}$. The $\mathrm{y}$-axis is in arbitrary units. 

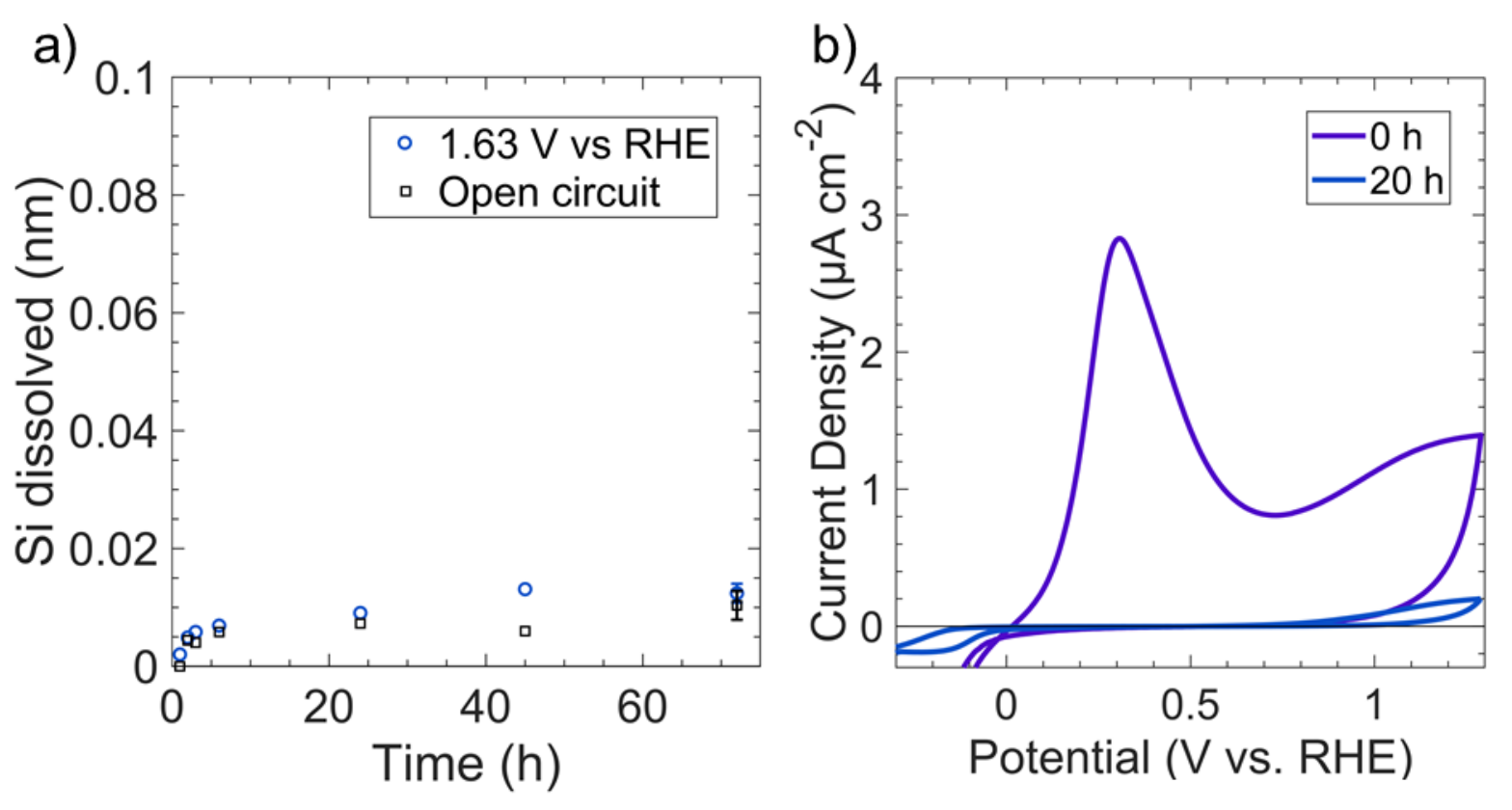

Figure S15. Stability of $\mathrm{SiO}_{\mathrm{x}}$ in $\mathrm{O}_{2}$-saturated 0.5 M K-borate buffer ( $\mathrm{pH}$ 9.5). (a) Si dissolved over time in solution from $\mathrm{p}^{+}-\mathrm{Si}$ electrodes at open circuit (black square) and at $1.63 \mathrm{~V}$ vs RHE (blue circle) as determined by inductively coupled plasma mass spectrometry. (b) Cyclic voltammograms of $\mathrm{p}^{+}$-Si electrodes measured either immediately after immersion (purple) or after $20 \mathrm{~h}$ at open circuit (blue). The voltammetric scan rate was $1 \mathrm{mV} \mathrm{s}^{-1}$. To remove any native oxide, the electrodes were immersed in buffer oxide etch for $30 \mathrm{~s}$ prior to electrochemistry. 


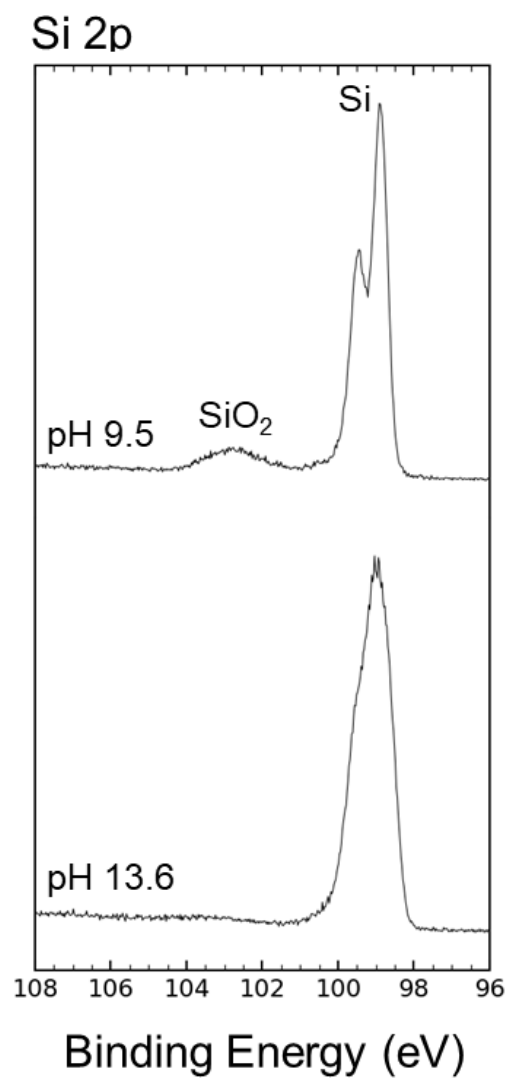

Figure S16. XPS data in the Si $2 \mathrm{p}$ region of $\mathrm{p}^{+}-\mathrm{Si}$ electrodes. Electrodes were measured after 20 $\mathrm{h}$ in $1 \mathrm{M} \mathrm{KOH}(\mathrm{aq})$ at open circuit in either $1 \mathrm{M} \mathrm{KOH}(\mathrm{aq})$ (bottom) or $0.5 \mathrm{M} \mathrm{K}$-borate buffer (top). The electrode was submerged in buffer oxide etch for $30 \mathrm{~s}$ to remove any native oxide prior to testing. The y-axis is in arbitrary units.

\section{References}

1. H. J. Fu, I. A. Moreno-Hernandez, P. Buabthong, K. M. Papadantonakis, B. S. Brunschwig and N. S. Lewis, Energy \& Environmental Science, 2020, 13, 4132-4141. 